\title{
BECOMING MENTORS: A NARRATIVE EXERCISE TO UNVEIL STRUGGLES GUIDING AN ENGLISH LANGUAGE TEACHING PRACTICUM
} ABRIÉNDONOS PASO COMO MENTORES: UN EJERCICIO NARRATIVO PARA DEVELAR LUCHAS ORIENTANDO UNA PRÁCTICA DOCENTE PARA LA ENSEÑANZA DEL INGLÉS

\author{
Pilar Méndez-Rivera ${ }^{1}$ \\ Francisco Pérez-Gómez ${ }^{2}$ \\ Universidad Pedagogica Nacional de Colombia
}

\begin{abstract}
This paper analyses the memories of two English language teachers recollected about their struggles to break through as practicum mentors in two public universities. This smallscale narrative study emerged from the constant and collaborative reflection upon their long years of experience advising primary and secondary schools' mentees, and upon the different situations mentors had to experience while performing their job. Findings revealed that despite having worked in two allegedly different settings, both mentors faced similar issues regarding their vision of education, their view

1 Doctora en Educación Universidad Distrital Francisco José de Caldas, pmendez@udistrital.edu.co. https:// orcid.org/0000-0001-9284-4611

$2 \quad$ Master in Teaching English as a Foreign Language, Faculty of Humanities, Universidad Pedagógica Nacional de Colombia, frankpego@yahoo.com https://orcid. org/0000-0002-0514-1609
\end{abstract}

on language and their own identity as teachers, which affected their guidance. They also found that the feedback they provided their mentees perpetuated or contradicted dominant visions where inclusion and diversity were neutralized.

\section{KEYWORDS:}

mentors; struggles; practicum; narratives; self; professional growth

\section{RESUMEN}

Este documento analiza las memorias de dos profesores de inglés acerca de sus dificultades para abrirse paso como mentores de práctica docente en dos universidades públicas. Este estudio a pequeña escala surgió de la reflexión constante y colaborativa sobre sus largos años de experiencia asesorando a los futuros docentes de 
inglés de las escuelas primarias y secundarias, y sobre las diferentes situaciones que tuvieron que experimentar al realizar su trabajo. Los hallazgos revelan que a pesar de trabajar en dos entornos supuestamente diferentes, ambos enfrentaron problemas similares con respecto a su visión de la educación, su visión del lenguaje y su propia identidad como maestros, lo cual afectó su orientación del proceso. También descubrieron que la retroalimentación que proporcionaron perpetuaba o contradecía visiones dominantes mientras la inclusión y la diversidad se neutralizaban.

PALABRAS CLAVE: mentores; luchas, práctica, narrativas, yo; crecimiento profesional

\section{RESUMO}

Este documento analisa as memórias de dois professores de inglês sobre suas dificuldades em se destacar como mentores de prática de ensino em duas universidades públicas. Este estudo em pequena escala surgiu de uma reflexão constante e colaborativa sobre seus longos anos de experiência aconselhando futuros professores de inglês em escolas primárias e secundárias e sobre as diferentes situações que eles tiveram que vivenciar durante a realização de seu trabalho. Os achados revelam que, apesar de trabalharem em dois ambientes supostamente distintos, ambos enfrentaram problemas semelhantes em relação à sua visão de educação, sua visão de linguagem e sua própria identidade como professores, o que afetou sua orientação para o processo. Eles também descobriram que o feedback que forneciam perpetuava ou contradizia as visões dominantes, enquanto a inclusão e a diversidade eram neutralizadas.

\section{PALAVRAS-CHAVE:}

mentores; lutas, prática, narrativas, eu; crescimento profissional

\section{INTRODUCTION}

Central to this study is a concern with the process of becoming mentors and the demands of an inquiry-based practicum to transform teacher educators into mentors capable of helping student-teachers to see themselves as educators and not only as English teachers. The study uses an analysis of two mentors' narratives to explore fundamental questions in terms of their preparedness, roles, work conditions, institutional constraints and demands, and their own professional growth. Such questions were instrumental in their interpellation as to their constitution as mentor subjects and the construction of meaning to support an inquirybased practicum. The importance of this study relies on the self-exposure of mentors' struggles to reveal fears, critiques, self-questioning and understandings of what has been their history to become mentors and how this endeavor has transformed them. Equally central, there is a focus on the ways mentors recognize how they have become themselves instruments to normalize students, ideal models of teaching and teachers that obscured student -teachers' voices, ideas and identities.

Mentors' roles have been broadly studied (Bray and Nettleton, 2006; Mpofu, J. \& Chimhenga, S., 2016; Maphalala, M. C., 2013; and Tang, 2003). Some of these studies have been oriented in a prescriptive way, providing a list of characteristics that mentors must meet, no matter which contexts they have to face (Podsen \& Denmark, 2000; Portner, 1998) which can be understood as the definition of an essentialized self (Butler, 1990). Some other works have presented important reflections to undermine a prescriptive view of mentors, showing the difficulties and the importance of a person who really cares about their student-teachers developing their own potentialities and competencies (Boreen et al., 2000, Bonilla \& Autor, 2008). The contribution of this particular paper to the field of EFL 
education lies in a self-critical reflection of two educators describing the process of becoming mentors, showing gaps, mishaps and insights that, although unveiling their contribution to the practicum, also admit how they somehow exercised inadvertently exclusionary practices of diversity (e.g. student-teachers' backgrounds) and student -teachers' positioning.

This research was built upon narratives which at a first glance might seem only about telling and retelling experiences we live while performing our job as mentors; nevertheless, inquiring through narratives implies more than telling a story since it is quite a complex process made up of several phases (Clandinin \& Pushor, 2007). Our aim was to examine the experiences recounted in the shared professional setting in order to unveil how our own selves had been confronted, challenged, and transformed while becoming mentors.

\section{THEORETICAL INSIGHTS}

A remarkable trend towards mentors' roles has influenced the construction of an essentialized identity, more related to effectiveness and success (Bray and Nettleton, 2006; Mpofu, J. \& Chimhenga, S., 2016; Maphalala, M. C., 2013; Tang, 2003, Podsen \& Denmark, 2000; Portner, 1998) rather than an identity construction, and affected by conflicting experience and context. Going deeper into this, we would like to pose a set of queries that have always been lingering in literature on EFL and mentoring. These are as follows: instead of thinking of a mentor as a "given" someone, why not think of the intricated acts of becoming one for self-reflective practices? Can every teacher be a mentor just because they are teachers? What kind of struggles do teachers experience and are fundamental to embrace this identity? Is it easy to be a mentor or is it a daunting task? What else do mentors do aside from checking lesson plans and instructional designs, as well as conducting observations? Can they be conceived of as a source of inspiration or, conversely, as a subject of control to be resisted? Is their job valued or undervalued? These questions have been a matter of discussion for scholars and researchers who have tried to shed light on the importance of mentoring in teachers' education for complex and diverse practicum scenarios (Mpofu, J. \& Chimhenga, S., 2016; Maphalala, M. C., 2013; Tang, 2003; McCormack \& West, 2006; Smith, 2007; Fairbanks, Freedman \& Kahn, 2000; Bray \& Nettleton, 2006). By means of inquiring as mentors, we recognize that this study has been shaped by our very own experiences and worries about our changes throughout time and across space. In this sense, we attribute to reflection practices an important value to expose correlated forces involved in the process of becoming mentors inspired by works done in the field of narratives and identity construction (De Costa, 2015; Tsui, A.B.M., 2007), and the philosophical work of Foucault in the care of self (1986) and technologies of self (1988).

Revisiting the literature consulted, we came across the fact that there are underlying agreements among authors on the supportive nature of mentoring and the background importance together with experience and expertise gained by mentors as key factors in the success of practicum for institutions (Ulvik \& Smith 2011, Graves, 2010, Ambrosetti, 2012; Ambrosetti \& Dekkers, 2010) Another aspect that has been identified is a change in view from supervisor and evaluators to mentors (Bray, \& Nettleton, 2006). What we have not found yet is the problematization of what it entails to become an EFL mentor and the implication it has for the development of a more egalitarian and inclusive teacher education practice. It is relevant to understand the complex nature of education, and the need for a professional growth of mentors oriented to promote social change, advocating for a contextualized and situated practicum. Most of the studies reviewed are student-teacher centered in the sense that they focus on didactic, 
methodological and instructional issues such as classroom management, lesson planning, instructional design, and language use, to mention a few, but none of them remarks on a curricular transformation of the reality where mentors and student-teachers perform in and of their own reality.

In fact, most of research in the field revolves around the role of mentors as something granted and prescribed, yet it invisibilizes and minimizes the struggles suffered (undergone?) by teachers in their process of becoming mentors and, to some extent, how they cope with ethical and professional frustrations. Some of these studies have particularly considered the difficulties faced by mentors in terms of instrumental matters (Bullough, R.V., 2005; Jones, M., 2010) but have not explicated the intricate struggle of self to perform their tasks in a terrain full of conflictsboth internal and external-that are not only focused on ethical and practical but also on theoretical considerations.

As mentors, we have witnessed how some colleagues, after considering that being a mentor could be performed easily, embarked suddenly upon this overwhelming mission. Once they lived the experience for the first time and realized the amount of duties this job implied (linguistic, professional, moral, ethic, social, research, administrative and leadership, etc.), they decided radically to drop out of the practicum. Having that in mind, we wonder how it is possible that despite being a time-consuming and strenuous activity, there are teachers as ourselves who persist in being mentors, love doing it and withstand all those pressures arising from different directions (from the schools, from teacher-education programs, from studentteachers and, strikingly, in the good sense of the word, from themselves).

\section{METHODOLOGY}

This small-scale qualitative study was inspired by the narrative turn. The foundations to conduct a study of this nature were brought about by Labov (2001), who explains that a narrative is a way to report past events that have entered the biography of the narrator (p. 63). According to Chase, S. (2018), the growing maturity in the narrative inquiry field has expanded this limited notion of narrative as a 'report' to a more encompassing one that defines it as instances of social actions with a clear intention of doing something as either entertaining or persuading (p. 547). Not only is this based on past events but upon present, future and even hypothetical experiences. The importance of narrative inquiry in Clandinin and Pushor's (2007) words relies on its potentiality to unveil teachers' knowledge about a specific topic and to contribute to social change (Squire et al., 2013). In the field of ELT, Norton, B. (2013), Johnson, K. \& Golombeck, P. (2011), and Barkhuizen, G. (2008) have offered insightful perspectives to connect narratives to the study of teachers' identity. In our case, this study emerged from an unexplored angle of a previous work devised by ourselves (Autor \& Autor, 2017), in which we were describing and analyzing student-teachers' difficulties in their practicum and in doing so, we were sharing our own stories and pinpointing difficulties and goals; surprisingly, these difficulties were fundamental to affirm our identity as mentors but more striking were the anecdotes, personal experiences, fears, mistakes, and even self-mockery that revealed the struggles of the self that needed to be told in the process of becoming a mentor.

\section{INSTRUMENTS}

To make sense of our own experience, we answered a questionnaire with 5 open questions in a narrative form to give account of the lived experience while becoming mentors. The narratives followed a chronological arrangement from past to present. While dialoguing, we 
took notes about new relevant information intended to complete gaps or indicate new ways of seeing things that had not been said in the narrative. Then, we shared our views and discussed how some of the issues were going to be treated (i.e. institutional information and perturbing information) while considering ethical considerations and the most valuable information to extract.

Table 1. Key questions (February 10, 2020)

1. How did you break through as a mentor?

2. In the process of becoming a mentor, have you changed your view on language teaching?

3. Do you feel that you have grown professionally while performing as a mentor?

4. Have you questioned your role as a mentor? Explain the reasons.

\section{PROCEDURES}

In this exploratory analysis of the narratives, we made sense of the data prioritizing relevant information collected through written and oral responses. A list of thematic units was displayed as a result of a cross-referenced analysis of the two narratives in relation to enrollment in practicum, professional development and mentorship practices. Information gathered in the form of notes was a complementary source to discuss findings in terms of commonalities or differences between the paths both participants had taken to become mentors such as preparedness, professional development courses and autonomous studies.

\section{PARTICIPANTS}

Participant 1. F studied at a former Normal school (high schools where students trained to become teachers) and moved to the capital city of Colombia to study in a program for language teaching. With that in mind, he enrolled in the foreign language department at a well-known public university which forms prospective teachers. As soon as he finished his major in languages in 1995, he was offered the possibility to work as a part-time English teacher. In 2009, he was given the opportunity to be a practicum advisor, and since then he has been a mentor for the language department where he studied his undergraduate program. Afterwards, he earned a master's degree in teaching Spanish as a foreign language and completed another master's degree in English as a Foreign language.

Participant 2. P started her major in modern languages at a public university in her hometown at night. She came to Bogotá to do her master's degree in Spanish linguistics. She got a few hours to teach at a public university and, in 2004 she joined the teaching practicum in high school for language students enrolled at that university. Since then she has been performing this job. In 2007. In 2014, she obtained her doctoral degree in education at a private institution.

\section{RESULTS}

This section discusses the main findings of the research. A thematic organization of data is provided to cast light upon four important aspects. First, the ways both teachers became mentors, discussing their enrollment process at universities (from emerging teachers to committed mentors), second, the participants' cut-moments to describe vision of language and its effects on mentoring (from restrictive views to dynamic visions of language); third, gains and learnings from this subject position 
(ourselves as mentors) and fourth, criticism and remorse to problematize hegemonic practices (normalization, exclusion and marginalization).

\section{FROM EMERGING TEACHERS TO COMMITTED MENTORS}

This first category helps us to comprehend the transition that both teachers experienced prior to becoming mentors. Both educators discussed the process through which they were appointed mentors. In F's views the most decisive factor to get him enrolled as a practicum supervisor was his local experience and reputation for being a good teacher. That local experience that allowed him to get that job was also depicted in the fact that he was an alumnus from that university:

F: I think they assigned me the position of practicum supervisor taking into account the fact that I knew the university curriculum and the practicum itself because I had graduated from there. Another factor that I believe influenced their decision to assign me some hours to advise practitioners had to do with the fact that I had received good appraisals from my bosses and the approval of my undergraduate students. I doubt very much that my academic formation as a normalista, my experience as a teacher at schools were not decisive in my enrollment as a practicum mentor, I mean as a supervisor, as they used to call us.

$\mathbf{P}$ agrees with $\mathrm{F}$ on the fact that they did not ask to be mentors; she was chosen to be one. She stressed the idea that the figure of a mentor or even a supervisor was unfamiliar to her because all she had gone through in her practicum as an undergraduate student had to be dealt with by herself without any support from the university or from a mentor. She recognized that she was given the opportunity to work as a supervisor despite not having experience in the field, which is a common trend in our country; as much as it is highly desirable that mentors do have previous experience, institutions are forced to enroll new teachers because the position needs to be filled which, in words of Graham (2006); Korthagen \& Vasalos (2005), and Zeichner (2002) means that mentors have not been educated to perform their roles and that they are chosen at random.

P: Practicum came over to me suddenly because the practicum staff was terribly busy, and they could not take on any more practicum groups. My coordinator at that time was hesitant whether assign me the group, she posed me several questions such as: Do you have experience guiding practitioners? Have you worked in schools before? Are you willing to learn how to be a practicum supervisor, considering how hard this job is? As I am a risk taker, I decided to take on the responsibility, and agreed to be a practicum supervisor for high schools as I had no experience in primary schools.

Literature about the training and preparedness of mentors in Latin America is quite scarce and globally there is a tendency to advocate for that training and preparedness process (Ulvik, M. \& Smith, K. (2011); Bullough, 2005; Jones, 2010; Wilson, 2006; Graham, 2006; Korthagen \& Vasalos, 2005; and Zeichner, 2002). These authors reiterate the transcendental value that experience is acquired? in the job of mentors; for instance, Ulvik, M. \& Smith, K. (2011), based on Dewey, suggest the laboratory model as a complement to the apprentice model (mentors as models of expertise to be imitated). This laboratory model means that mentors' experience might serve as a vehicle to foster interpretations, reflections, and dialogs with student-teachers, which comes closer to the essence of the Bildung Model more than to the training one (pp.520-521). 
Moreover, it is evident that in the literature reviewed, there is a consensus that "a good teacher is not necessarily a good mentor" (Bullough, 2005; Jones, 2010; and Le Cornu, 2009), which implies the idea of investment in the process of mentors' constitution. This can be explained in the sense that a teacher needs to work on himself/herself to fulfill student-teachers' expectations during their practicum. Wilson (2006) points out that the 'role of mentors' is prone to changing from setting to setting. Some mentors, in his view, tend to describe their own impact as slight while others will 'defend their role in the practicum' (p. 523). This has been clearly attested in institutions where in spite of guidelines in the Bildung Approach, mentors adhere to the minimum of their duties and do not allow interaction with their student-teachers, nor do they get to comprehend the practicum setting where the latter perform. In terms of the commonalities found in the two narratives, it can be stated that teachers who decide to accept the mentoring task have to struggle to fit in the practicum system, advocating for their recognition and their self-professional growth.

\section{FROM RESTRICTIVE VIEWS TO DYNAMIC VISIONS ON LANGUAGE}

This category depicts how mentors shifted their views in terms of language. There were three clear-cut moments: the structuralist and purist model of language; the context-value approach to language and an identity-positioning teaching approach. These moments portrayed the struggles of teachers to respond to effectiveness and to the historical forces and regnant pedagogical trends in their institutions. Needless to say, one cannot become detached from the context and the conditions of the workplace; struggles occur as an ongoing and unstoppable process.
F. At an early start, I tended to worry too much about two things: first, that practitioners followed their lesson plan to the best of what was written, as the way actors follow a script without improvising, probably because that was the way my practicum supervisor got me into when I was studying to become a teacher at a Normal school. In this sense, to me class was predictable, it should have three moments as a story goes: beginning, a knot and resolution, pretty much the same no matter the level, no matter the school. Secondly, I would not tolerate the use of mother tongue by my practitioners in English class, despite I used to provide them with feedback on didactic and pedagogic affairs, I feel a large part of it was inclined to their language use. It seems language for me was not a means but was the end.

P. When I began to be a supervisor, I remember vividly that I took lots of notes on the language errors my practitioners committed. These notes had to do with other aspects such as time management and procedural things like the way they used the board or the way they projected their voice. Among everything, there was something that called my attention, the material they designed had to be colorful, carefully tailored and appealing. That absolutely blew my mind away. This reveals that my view on teaching was narrow and instrumental. As for language, what I was mostly concerned with was phonology and phonetics. I urged my practitioners to include pronunciation as a must in their lessons, and I hated their saying "repeat after me" as that was the trend back then. 
1.Structuralist and purist model of language: A common aspect that popped up in both narratives has to do with the acceptance and acknowledgment the mentors made of their restrictive view on teaching, deeply embodied and framed within their instrumental view on language, which was in tone with the historical, cultural paradigm of Grammar-Focus Approach. Consequently, this restrictive view affected the way they conceived student-teachers and English teaching in a Skilled-Based Approach. According to Wang, Odell and Schwille (2008), mentors' beliefs derive from the way they theorize the education their mentees shall receive and this, in turn, is reflected in their devotion and commitment in their workplace.

While holding talks on narratives, mentors highlighted that in a practicum process all participants involved should grow professionally, looking for mutual recognition and understanding. Conversely, narratives revealed that their focus on the practicum was centered only on the effectiveness or ineffectiveness of a class, so class and school policies had to be followed, fostered and prioritized so as to cause a great impression and to validate that the practicum was working well. Here, mentors were instruments of control and regulation imposing their views and denying student-teachers the possibility of being themselves.

Mentors agreed in their narratives that they favored a prevailing target language focus: the English-only policy, which contradicted the urgent needs of the context. This only English view has been a trend up to now. This exclusive view does not go hand in hand with intercultural perspectives to decolonize the teaching of languages in our country. So, this is an example of the perpetuation of a harmful monolithic view of bilingualism exerted by teachers in which total immersion is a tacit denial of identity.

F...well, as time went by, I grew up as a mentor when I started to value the job they did in their schools; I understood that my role exceeded that of making observations, taking notes and checking lessons plans; it had to include inevitably visiting the school with different perspectives, trying to understand the difficult environment where they were, which implied listening more to them, to their concerns, to their problems. I came to realize that even if they were studying to become language teachers there were other things they could do in their classes and that for instance, Spanish did not represent a hazard as I used to think, but a help at certain moments.

P...I am sure that experience is a key factor, I began to question myself about what I could do to help my practitioners to be better. I think I started to open up to new things, to start detaching myself from "job rituals"; this granted me a more school and society centered view than a language- based one. Pieces of advice, my inability to give an answer to every single question they asked me, made me feel a bit more aware that being a teacher goes beyond the confinement in a classroom, I quit worrying about the form, and began to worry about the essence, what can be done with languages.

2. The context-value approach to language: Acknowledging that the notion of change is overwhelming, Mr. John Mpofu and Dr Sylod Chimhenga (2016) state that mentors should perform as agents that champion for changes. It means working on their own selves (Foucault, 1986) in order to change attitudes, to set the ground for their own growth scaffolding, and to avoid mismatches between their beliefs and their practices. It is clear that a transition from being a supervisor to being a mentor was the result of the experiences the mentors were living, and not 
of the application of any theory that started to emerge at that time.

F... if you ask me, I kind of feel I have changed quite a lot compared to my first experiences as a mentor. Now, I do not go bananas about them using Spanish, especially if the method, approach or circumstances allow it. I understand that being a student-teacher is a crucial moment in their professional growth, and this should not necessarily be traumatic and painful. I do not like predictable classes anymore in terms of the way they are structured and given, contrary to this I enjoy observing lessons that change according to the situation and where they make on-thespot decisions when the planned thing does not work. Now, I like creativity over flawless classes. I have understood that they, as prospective teachers, bring on a lot to practicum.

$\mathrm{P}$ : getting rid of the ideal model of teachers in my brains, has allowed me to get to know my student-teachers better. I am interested in finding out what worries them, what makes them panic when they are teaching, and more importantly, how they see themselves as teachers. I encourage them to fight for their own ideals in their classes, and I like making myself valued and accountable for them. I do not feel comfortable when they somehow undervalue my role or reject me purposely or not. I value studentteachers who are really committed to their students' learning process. For me teaching a language implies a long -term process they should enjoy themselves and make their students enjoy.

3. An identity-positioning teaching approach: identity features are commonly challenged to value particular aspects of the advising process, the constructed feedback and the way mentors and mentees position themselves towards an event. In this pursuit for an identity, mentors praise how important it is to direct their perspectives to a more humanistic and critically-oriented view of education where, for instance, creativity is welcome and the studentteachers, in their attempt to transform their practicum setting, adjust teaching approaches and methods to their situated learning context i.e. to their needs accordingly (Fajardo et al. 2015; Autor, P. \& Autor-Autor, F. 2017; Bonilla, S. \& Autor, P. 2008).

\section{PERPETUATING EXCLUSION AND MARGINALIZATION}

A common aspect that revealed that both mentors had come to understand this fact is the guilt and remorse they expressed about it. Mentors acknowledged the way they were instruments to execute mechanisms of control (Foucault,1982; Bernstein, B., 1990), which were pervasive at some point to the practicum's sake and to the detriment of mentees. These feeling can be identified as emotional components of the inner struggles that now can be related to the impact of hegemonic discourses about how to be and how to teach, where some exclusionary practices were ruled by the practicum system to cast away those student-teachers who did not comply with the mandated profile.

F. It is very hard to talk about this without feeling guilty and remorseful. I feel that One unconsciously can segregate someone badly. I remember I used to remark that my student-teachers could not be shy in a class, that even if they were so shy and introvert, all of them without exception had to make an effort to look dynamic, convincing and self-confident. Now, I try to encourage my mentees to lead activities and use approaches where they feel confident and where they do not neglect or 
betray their own being. ...I think that I also fostered some kind of exclusion through evaluation because when I was a novel mentor I focused mainly on classroom management, language use and class organization and on the ones that in principle did not show a great performance were at a disadvantage in relation to the ones that were ahead.

P: I remember regrettably that by means of some supervising and controlling practices that I wanted to cultivate to ensure that they were good teachers, I used to undervalue those practitioners whom I labelled as very shy, also I remember I would praise a lot those student-teachers who had a native-like pronunciation, up to the point that some students were invisibilized and even deprived of the opportunity to continue with their practicum because of their not being linguistically and didactically competent. I missed the chance to know them and to help them as it was due. (...) It is sad that I replicated exclusionary practices with students who needed my support and were just starting their teaching career. I know that some of them might hate me and might think of me as evil-hearted, but I was complying with practicum policies and what the system established at that moment.

Rules imposed within the native-speakerism model remain uncovered in the curriculum (Posner, 2004). The role of mentors is to encourage mentees to raise awareness so that they are ready to resist. Depending on their capacity to resist those hegemonic discourses, mentors can or cannot be perpetuators of exclusionary practices. Needless to say, there are several factors such as the position they occupy in their workplace, their workload, the kind of contract they have (full-timers vs part- timers), and the experiences they have accrued that may hinder that possibility of resistance.

For instance, some mentors' meetings become instrumental in that perpetuation as they have to submit reports on the way mentees fulfill instructional policies and improve in terms of teaching and linguistic skills, prioritizing the ones that meet the standards and disqualifying those who do not. The experience of both mentors differed in the freedom to propose alternative views. For example, in P's case, she acknowledged that she enjoyed the privilege of being full-time and tenured and had had the opportunity to conduct institutionalized research projects, as well as to speak frankly and openly about issues related to the practicum. Whereas in the case of $F$, as a part-timer he felt silenced, even intimidated as to having his say about critical issues in relation to himself and his coordinator; that is to say, he felt he did not belong to a community of practice. Ideally, he would love to have a full-time position so as to devote to practicum as it deserves.

\section{CONCLUSIONS}

This study revealed that narratives served to unveil critical moments in the process of becoming mentors in which practices of selfquestioning denounced the existence of hegemonic discourses, practices, attitudes and behaviors that influenced deeply the way mentors perceive their mentees, themselves, the practicum and education nowadays. It is a claim that education must be a scenario for social change, and that in this sense, mentors are called to be agents of change and contribute to create the conditions for their mentees to cooperate in this pursuit.

Furthermore, narratives were fundamental to acknowledge that reflection, inquiry and decisions that mentors made at some point had a great incidence and repercussion on their student-teachers and on themselves. Through 
reflection and constant inquiry, mentors could recognize that they were evolving as educators, and that process is one that is mediated by time, space, external factors, commitment and investment.

\section{BIBLIOGRAPHIC REFERENCES}

Ambrosetti, A (2012). The impact of preparing mentor teachers for mentoring. Joint AARE APERA International Conference, Sydney.

Ambrosetti, A. \& Dekkers, J. (2010). The interconnectedness of the roles of mentors and mentees in preservice teacher education mentoring relationships. Australian Journal of Teacher Education, 35(6), 42-55. http:// dx.doi.org/10.14221/ajte.2010v35n6.3

Barkhuizen, G. (2008). Narrative reflective writing: "It got easier as I went along". Brasileira de Lingüística Aplicada, v. 8, n. 2, 2008. http://dx.doi.org/10.1590/ S1984-63982008000200006.

Beck, S. (2001). Editor's Reviews of Vygotskian Perspectives on Literacy Research: Constructing meaning through collaborative inquiry and inside city schools: Investigating Literacy in multicultural Classrooms. Harvard Educational Review, 71(2), 296-310. http://doi.org/10.17763/ haer.71.2.c10541380w62g260

Bernstein, B. (1990). The Structuring of Pedagogic Discourse. Volume IV. Class, codes and control. London and New York: Routledge Class.
Bonilla, S., \& Autor Autor, P. (2008). Mentoring in pre-service teaching: from reflection on practice to a didactic proposal. Actualidades Pedagógicas, O(52), 79-90. doi:http://dx.doi. org/10.19052/ap.1328

Boreen, J., Johnson, M. K., Niday, D., \& Potts, J. (2000). Mentoring beginning teachers: Guiding, reflecting, coaching. York, ME: Stenhouse Publishers.

Bray, L. \& Nettleton, P. (2006). Assessor or mentor? Role confusion in professional education. Nurse Education Today, 27, 848-855. doi: 10.1016/j. nedt.2006.11.006

Bullough, R.V. (2005). Being and becoming a mentor: School-based teacher educators and teacher educator identity. Teaching and Teacher Education, 21(2), 143-155.

Butler, J. (1995). Collected and Fractured: Responses to Identities. In: Appiah, Kwame Anthony / Gates, Henry Louis (eds.): Identities. Chicago, p. 439-447.

Clandinin, D. J., D. Pushor, \& A. M. Orr. (2007). "Navigating Sites for Narrative Inquiry." Journal of Teacher Education 58: 21-35.

Chase, S. (2018). Narrative Inquiry: toward theoretical and methodological maturity. In Denzin \& Lincoln (Editors). The Sage Handbook of Qualitative Research. Sage Publishing.

De Costa, P. (2015). Tracing Reflexivity Through a Narrative and Identity Lens. Cheung, Y.L, Said, S.B. \& Park, K. (Editors). Advances and Current Trends in Language Teacher Identity Research. Routledge: New York. 
Fairbanks, C. M., Freedman, D. \& Kahn, C. (2000). The role of effective mentors in learning to teach. Journal of Teacher Education, 51(2), 102 -112.

Fajardo Castañeda, J.A. \& Miranda Montenegro, I. R. (2015). The paradox of the practicum: Affinity to and resistance towards teaching. Íkala, Revista de Lenguaje y Cultura, 20(3), 329-341. Doi: 10.17533/udea.ikala.v20n3a04

Foucault, M. (1986). The care of the self. The history of sexuality 3. Trans. R. Hurley. New York: Pantheon Books.

Foucault, M. (1982). The Subject and Power. Critical Inquiry 8 (4), p. 777-795.

Graham, B. (2006). Conditions for successful field experiences: Perceptions of cooperating teachers. Teacher and Teacher Education, 22: 1118-1129.

Graves, S. (2010). Mentoring pre-service teachers: A case study. Australasian Journal of Early Childhood, 35(4), 14-20. http://dx.doi. org/10.1080/00220670209596597

Johnson, K. E. and Golombek, P. R. (2011), The Transformative Power of Narrative in Second Language Teacher Education. TESOL Quarterly, 45: 486-509. doi:10.5054/tq.2011.256797

Jones, M. (2010). The needs of mentors. In K. Smith \& M. Ulvik, Veiledning av nye lærere. Nasjonale og internasjonale perspektiver. Oslo: Universitetsforlaget.

Maphalala, M. C. (2013). Understanding the Role of Mentor Teachers during Teaching Practice Session. Int $J$ Edu Sci, 5(2): 123-130. DOI: 10.1080/09751122.2013.11890069.
McCormack, C., \& West, D. (2006). Facilitated group mentoring develops key career competencies for university women: a case study. Mentoring \& Tutoring, 14(4), 409-431.

Méndez, P. and Gómez-Pérez, F. (2017). Understanding Student-Teachers' Performances within an Inquiry-Based Practicum. English Language Teaching; Vol. 10, No. 4; 2017. DOI: https://doi. org/10.5539/elt.v10n4p127

Mpofu, J. \& Chimhenga, S. (2016). The Importance of Mentoring: Findings from Students Doing Post Graduate Diploma in Education at Zimbabwe Open University, Bulawayo Region. Journal of Research \& Method in Education 6/3:27-31.

Norton, B. (2013). Identity and Language Learning. Extending the Conversation. Multilingual Matters

Podsen, I. J., \& Denmark, V. M. (2000). Coaching and mentoring first-year and student teachers. New York: Eye on Education.

Portner, H. (1998). Mentoring new teachers. Thousand Oaks, CA: Corwin Press.

Posner, G. (2004). Análisis del currículo. México: McGraw-Hill.

Pushor, D., \& D. J. Clandinin. 2009. The Interconnections Between Narrative Inquiry and Action Research. In The Sage Handbook of Educational Action Research, Eds. S. Noffke \& B. Somekh, 290-300. Thousand Oaks, CA: Sage.

Tang, S. Y. F. (2003). Challenge and support: the dynamics of student teachers' professional learning in the field experience. Teaching and Teacher Education, 19, 483-498. doi:10.1016/ 
S0742-051X (03)00047-7

Tsui, A.B.M. (2007). Complexities of identity formation: A narrative inquiry of an EFL teacher. TESOL Quarterly, 41(4), 657680. DOI: 10.1002/j.1545-7249. 2007. Tb 00098.x.

Ulvik, M. \& Smith, K. (2011). What characterises a good practicum in teacher education? Education Inquiry, 2(3), pp.517-536. DOI: 10.3402/edui.v2i3.21997

Wang, J., Odell, S. J. and Schwille, S.A. (2008) Effects of teacher induction on beginning teachers' teaching, Journal of Teacher Education, 59 (2) 132-151. 